\title{
Mergers and acquisitions involving UK companies
}

\section{1st quarter 2011}

\section{Date: 7 June 2011}

\section{Coverage: United Kingdom Theme: Commerce, energy and industry}

This statistical bulletin provides data on the value and number of mergers, acquisitions and disposals involving UK companies with values over $£ 1.0$ million. Key findings include:

- The value of acquisitions abroad by UK companies rose to $£ 18.3$ billion in quarter one 2011 from £3.8 billion in quarter four 2010.

This is the highest reported value for outward investment since quarter four 2007.

- Expenditure on acquisitions in the UK by foreign companies fell slightly to $£ 6.4$ billion in quarter one 2011 from $£ 7.0$ billion the previous quarter.

- Expenditure on acquisitions in the UK by UK companies fell to $£ 1.2$ billion in quarter one 2011 from $£ 6.3$ billion in quarter four 2010 .

Expenditure on acquisitions abroad by UK companies

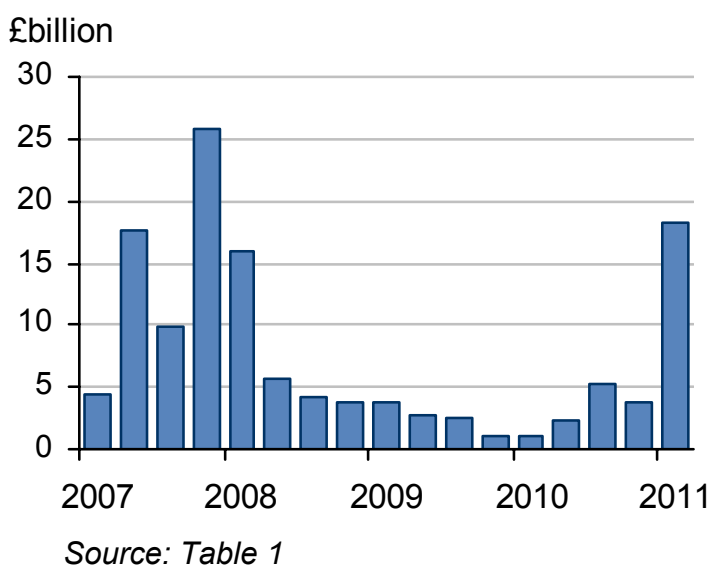

Number and value of mergers and acquisitions involving UK companies

\begin{tabular}{|c|c|c|c|c|c|c|}
\hline & \multicolumn{2}{|c|}{$\begin{array}{l}\text { Acquisitions abroad by UK } \\
\text { companies* }^{*}\end{array}$} & \multicolumn{2}{|c|}{$\begin{array}{l}\text { Acquisitions in the UK by } \\
\text { foreign companies* }\end{array}$} & \multicolumn{2}{|c|}{$\begin{array}{l}\text { Acquisitions in the UK by } \\
\text { UK companies* }\end{array}$} \\
\hline & Number & Value & Number & Value & Number & Value \\
\hline 2009 & 118 & 10.1 & 112 & 32.0 & 286 & 12.2 \\
\hline $2010 r$ & 199 & 12.4 & 212 & 36.6 & 325 & 12.6 \\
\hline 2009 Q4 & 41 & 1.0 & 34 & 15.1 & 77 & 1.4 \\
\hline 2010 Q1r & 30 & 1.0 & 54 & 14.4 & 67 & 1.4 \\
\hline 2010 Q2r & 49 & 2.3 & 48 & 2.8 & 95 & 2.0 \\
\hline 2010 Q3r & 54 & 5.3 & 59 & 12.4 & 80 & 2.9 \\
\hline 2010 Q4r & 66 & 3.8 & 51 & 7.0 & 83 & 6.3 \\
\hline 2011 Q1p & 48 & 18.3 & 38 & 6.4 & 60 & 1.2 \\
\hline
\end{tabular}




\section{Transactions abroad by UK companies}

\section{Number and value of transactions (Table 1)}

Expenditure on acquisitions abroad rose to $£ 18.3$ billion in quarter one 2011 from $£ 3.8$ billion in quarter four 2010. This is the highest reported value for quarterly outward investment since quarter four 2007.

This increase in the overall value was primarily due to the acquisition by International Power PIc of GDF Suez Energy International Holding Companies. This deal resulted in the subsequent acquisition of a 70 per cent stake in International Power PIc by GDF SUEZ in a 'reverse' takeover.

Despite the rise in the value of transactions, the number of acquisitions fell from the previous quarter. There were 48 acquisitions of foreign companies by UK companies with values over £1.0 million in quarter one 2011 compared with 66 in the previous quarter.

There were 14 disposals of foreign companies by UK companies in quarter one 2011 with a total value of $£ 1.1$ billion.

\section{Significant acquisitions abroad by UK companies} include:

\begin{tabular}{lc}
\multicolumn{1}{c}{ Value in $£$ million } \\
\hline $\begin{array}{l}\text { Yule Catto \& Co Plc acquiring PolymerLatex } \\
\text { Beteiligungsgesellschaft mbH }\end{array}$ & 376 \\
$\begin{array}{l}\text { Anglo American Plc disposing of Lisheen Zinc } \\
\text { Mine }\end{array}$ & $-336^{*}$ \\
$\begin{array}{l}\text { Vedanta Resources Plc acquiring Lisheen Zinc } \\
\text { Mine }\end{array}$ & $336^{*}$ \\
$\begin{array}{l}\text { Candover Investments Plc disposing of Equity } \\
\text { Trust Holding Sarl }\end{array}$ & $289^{*}$ \\
$\begin{array}{l}\text { Misys Plc acquiring Sophis Holding } \\
\text { (Luxembourg) SCA }\end{array}$ & 240 \\
$\begin{array}{l}\text { RSA Insurance Group Plc acquiring GCAN } \\
\text { Insurance Company }\end{array}$ & 221 \\
$\begin{array}{l}\text { RPC Group Ltd acquiring Superfos Industries } \\
\text { A/S }\end{array}$ & 205 \\
\hline
\end{tabular}

See background notes 2, 3, 6

* Value as reported in financial press or other public sources.

\section{Expenditure on acquisitions abroad by UK companies}

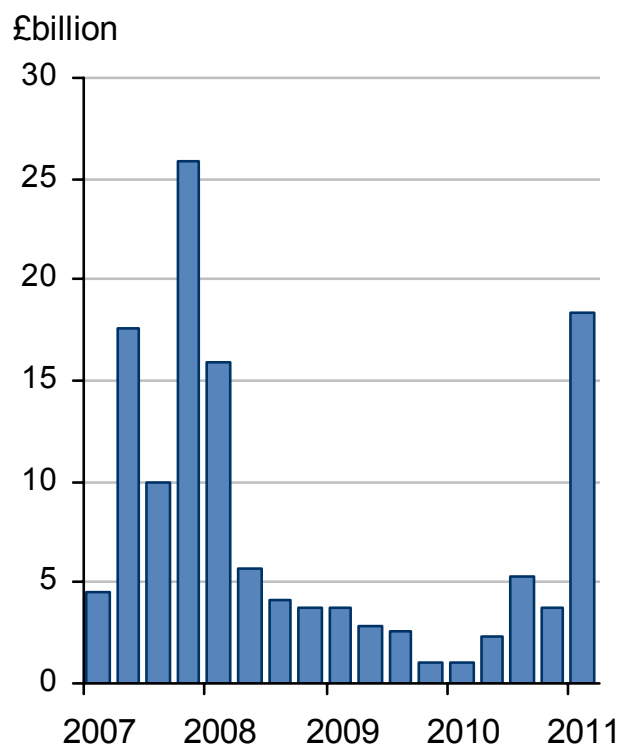

Source: Table 1

\section{Number of acquisitions abroad by UK companies}

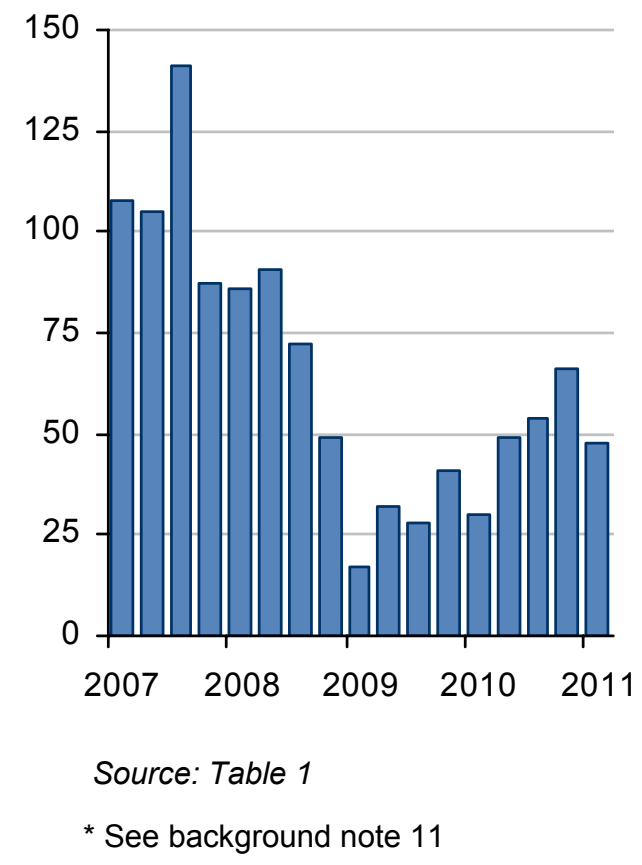




\section{Transactions in the UK by foreign companies}

\section{Number and value of transactions (Table 1)}

Expenditure on acquisitions abroad by UK companies fell slightly to $£ 6.4$ billion in quarter one 2011 from $£ 7.0$ billion in quarter four 2010. One large inward acquisition in quarter one 2011 was the acquisition of British Airways Plc by BA Holdco S.A. This transaction was part of the merger of British Airways Plc and Iberia, Líneas Aéreas de España, S.A. to create International Airlines Group.

The number of acquisitions also fell in quarter one. There were 38 acquisitions of foreign companies by UK companies with values over $£ 1.0$ million in quarter one 2011 , compared with 51 the previous quarter.

There were 12 disposals of UK companies by foreign companies in quarter one 2011 with a total value of $£ 0.7$ billion.

\section{Expenditure on acquisitions in the UK by foreign companies}

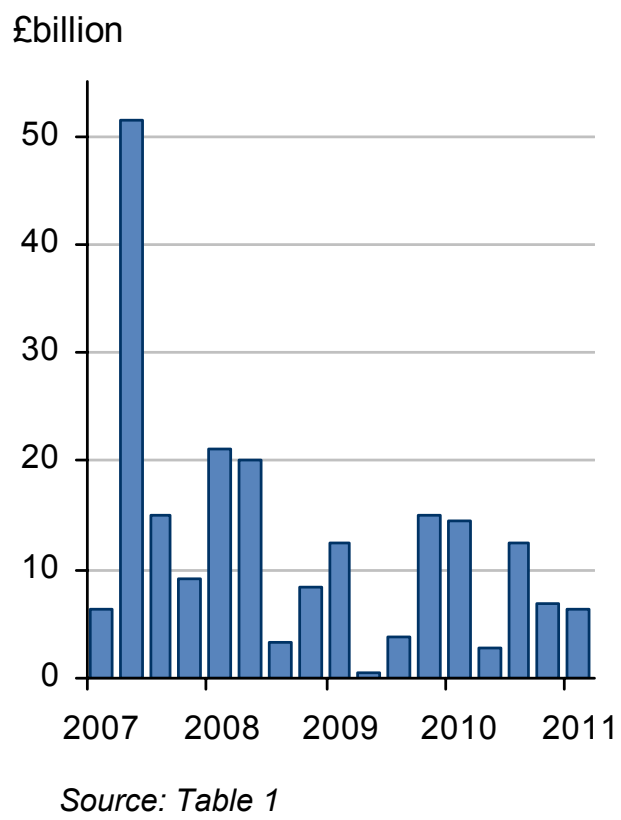

Significant transactions in the UK by foreign companies include:

\section{Number of acquisitions in the UK by foreign companies ${ }^{*}$}

General Electric Company
Wellstream Holdings Plc

Value in $£$ million

Laxey Partners Ltd disposing of Laxey

209*

Logistics Ltd

Norbert Dentressangle S.A acquiring Laxey

209*

Logistics Ltd

See background notes 2, 3,4

* Value as reported in financial press or other public sources.

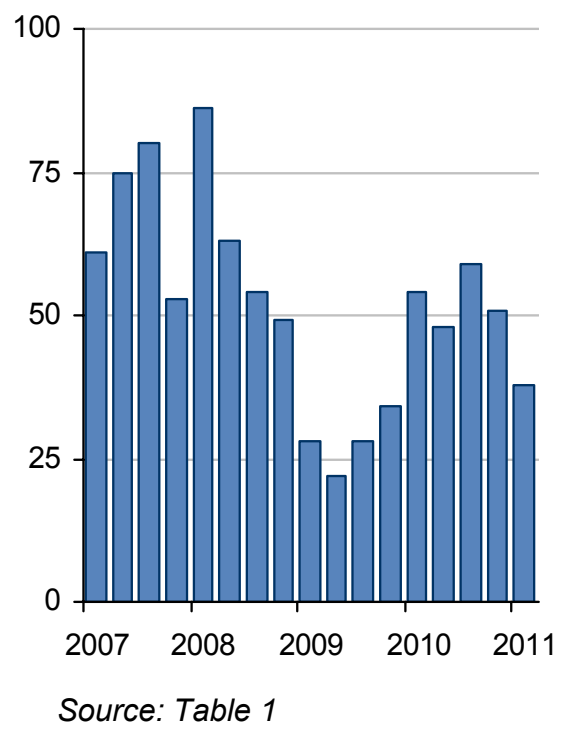

* See background note 11 


\section{Transactions in the UK by UK companies}

\section{Number and value of transactions (Table 8)}

Expenditure on acquisitions in the UK by UK companies fell to $£ 1.2$ billion in quarter one 2011 from $£ 6.3$ billion in quarter four 2010, the lowest value since quarter two 2009 and the second lowest value since quarter three 1992.

The largest domestic transaction in quarter one 2011 was the acquisition by BTG PIc of Biocompatibles International PIc for a reported value of $£ 0.2$ billion.

The number of acquisitions also fell in quarter one 2011. There were 60 acquisitions of UK companies by other UK companies with values over $£ 1.0$ million in quarter one 2011 , compared with 83 the previous quarter. These transactions consisted of 43 acquisitions of independent companies and 17 transactions by company groups involving their subsidiaries.

Significant transactions in the UK by UK companies include:

Value in $£$ million

BTG PIc acquiring Biocompatibles International

172

$\mathrm{PlC}$

Acromas Holdings Ltd acquiring Nestor Healthcare Group Plc

See background notes 2, 3, 5

* Value as reported in financial press or other public sources.

\section{Expenditure on acquisitions in the UK by UK companies}

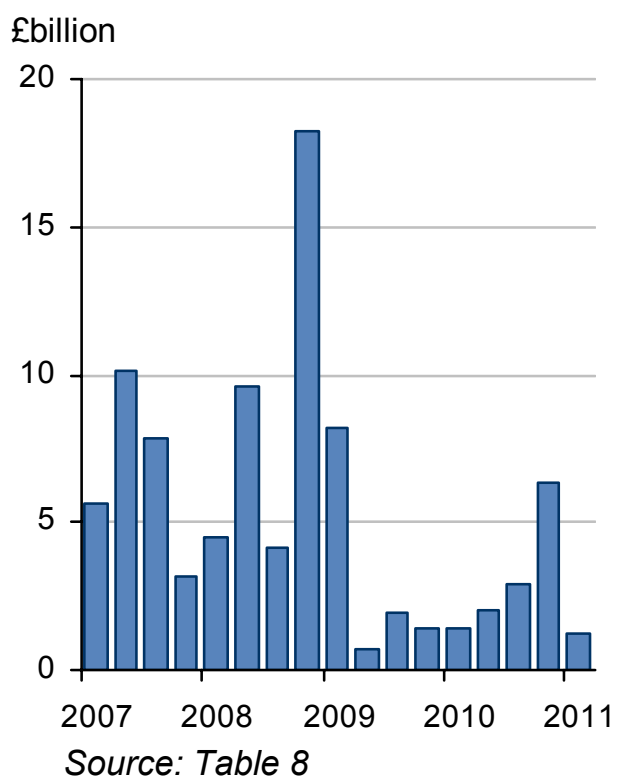

Number of acquisitions in the UK by UK companies*

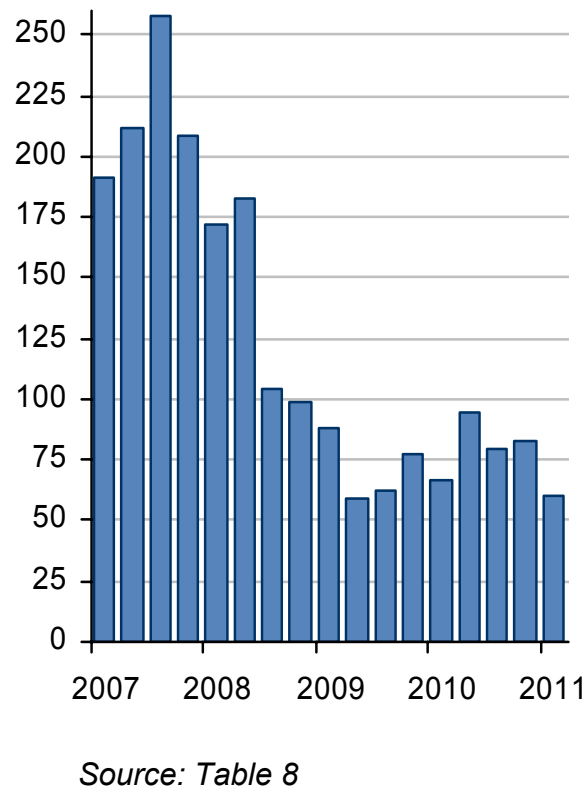

* See background note 11 


\section{Background Notes}

\section{Basic quality information}

1. Link to Summary Quality Report: A Summary Quality Report for Mergers and Acquisitions can be found at www.ons.gov.uk/about-statistics/methodology-and-quality/quality/qual-infoeconomic-social-and-bus-stats/quality-reports-for-business-statistics/index.html. This report describes in detail the intended uses of the statistics presented in this publication, their general quality and the methods used to produce them.

\section{Relevance to users}

2. Source of data: The information collected is based on reports in the financial press; specialist magazines; company and financial websites supplemented by special surveys to businesses to determine the form, value and timing of each transaction.

If the information is not yet in the public domain then such transactions may not be reflected in the analysis. Where full information has not yet been received on the details of the acquisition or disposal the value of the transaction indicated in the public domain is used as an interim estimate.

The data shown in this release relate solely to mergers and acquisitions undertaken by companies: deals relating to natural persons are not included.

\section{Significant transactions}

3. These tables show the reported figures for a selection of significant transactions which occurred in the quarter, where 'significance' is defined as the absolute value of the deal. The figures shown are usually the ones available from the financial press or other sources in the public domain although occasionally, with the consent of the company, the value returned to Office for National Statistics (ONS) is used in the tables instead of the press reported figure. If the company's consent cannot be obtained then the deal is excluded. Occasionally, therefore, a large deal may be missing from the lists so it is best to regard these tables as an indication of the ranking of deals rather than a completely exhaustive listing. Press reported figures often differ to some extent from those supplied by companies to ONS and it is the latter which are used in compiling statistical aggregates in tables 1-10. Included in the prices quoted in the tables of significant transactions is the total published price paid for the company excluding any assumed debt where known. Deferred payments are included in the reported price even if the payment is made in a different quarter.

\section{Types of transactions covered}

4. Cross border acquisitions denotes transactions where a company in one country acquires, either directly or indirectly, a controlling interest in a company in another country.

Direct transactions are those where a company in one country acquires a controlling interest in a company incorporated in another country.

Indirect transactions are those where a company uses an existing foreign subsidiary to acquire a controlling interest in a company incorporated in another country. The acquiring 
foreign intermediate company may be located in the same country in which the acquisition is being made or in a different country.

5. Acquisitions within the UK by UK companies: This denotes mergers and acquisitions involving only UK registered companies.

Where the acquired company was a subsidiary of another company the transaction is classified as a sale between company groups.

The phrase 'acquisitions in the UK by UK companies' refers to deals where the ultimate ownership remains in the UK. Consequently, this heading does not cover the total number or value of deals where a UK company is the acquirer. Where a foreign company acquires a UK company and achieves that acquisition by means of one of its existing UK subsidiaries that deal is shown as part of the data under 'acquisitions in the UK by foreign companies'.

\section{Financing}

6. This statistical bulletin provides details of the application of funds to effect mergers and acquisitions and the proceeds raised from disinvestments and demergers.

For indirect foreign transactions there is the added complication of considering the movements of funds either as capital injection or in the form of loans between parent companies and their foreign subsidiaries making the acquisition. Occasionally, the foreign subsidiary obtains the funds required partly or entirely outside the UK from sources such as:
a. Own resources
b. Borrowing from banks and other local sources
c. Share, bond and other capital or notes issued abroad

A transaction may be funded by more than one method.

\section{Accuracy}

7. Revisions to earlier periods: Data for quarters one, two, three and four 2010 have been revised in the light of new information. Subsequently revisions to past 2010 quarterly and annual data have been published in this statistical bulletin. Principle reasons for revisions are outlined in the Summary Quality Report linked in section 1 of the background notes. 


\section{Response rates}

8. Cross-border mergers and acquisitions (CBAM) inwards

Statistics of sample size - last survey conducted:

\begin{tabular}{lrr}
\hline Reference Period: & Quarter 4 2010 & Quarter 1 2011 \\
Response Rate (\%): & $73 \mathrm{r}$ & $74 \mathrm{p}$ \\
\hline
\end{tabular}

$r=$ revised $p=$ provisional

9. Cross-border mergers and acquisitions (CBAM) outwards

Statistics of sample size - latest survey conducted:

Reference Period:

Quarter 42010

Quarter 12011

Response Rate (\%):

$74 r$

$81 p$

$r=$ revised $p=$ provisional

10. Domestic mergers and acquisitions (DAM)

Statistics of sample size - latest survey conducted:

\begin{tabular}{lrr}
\hline Reference Period: & Quarter 4 2010 & Quarter 1 2011 \\
Response Rate (\%): & $88 \mathrm{r}$ & $79 p$ \\
\hline
\end{tabular}

$r=$ revised $p=$ provisional

\section{Notes to tables}

11. The deal identification threshold has been increased at quarter one 2010 to a value of $£ 1.0$ million from a previous value of $£ 0.1$ million. As a consequence there will be a discontinuity in the number of deals reported at quarter one 2010.

12. Symbols used in the tables are:

.. Figure suppressed to avoid disclosure of information relating to individual enterprises.

- Nil or less than half the final digit shown.

13. The sum of constituent items in tables may not always agree exactly with the totals shown due to rounding.

\section{Following ONS}

14. Follow us on www.twitter.com/statisticsONS or on Facebook.com/statisticsONS.

\section{Triennial Review}

15. We are currently conducting a review of the mergers and acquisitions surveys used to compile this statistical bulletin and we are inviting comments from everyone who uses the information we provide. If you would like to comment on how you use the information contained in this statistical bulletin or give your opinion of its quality and reliability, please contact Caroline Marks on 01633456646 or email caroline.marks@ons.gsi.gov.uk 


\section{Publication Policy}

16. Complete runs of series in this release are available to download free of charge at www.statistics.gov.uk/statbase/tsdintro.asp. Alternatively, for low-cost tailored data call Online Services on 02075335675 or email tailored@statistics.gov.uk

17. Details of the policy governing the release of new data are available from the Media Relations Office.

18. ONS will launch its new website on 28 August 2011, postponed from the original date of 30 April 2011. The new website will improve the way users can access our statistics, but many existing bookmarks and links will no longer work and users will need to update them. Find out more at www.ons.gov.uk/about/what-we-do/programmes---projects/webdevelopment/index.html

19. National Statistics are produced to high professional standards set out in the Code of Practice for Official Statistics. They undergo regular quality assurance reviews to ensure that they meet customer needs. They are produced free from any political interference.

(C) Crown copyright 2011.

You may re-use this information (not including logos) free of charge in any format or medium, under the terms of the Open Government Licence.

To view this licence, go to www.nationalarchives.gov.uk/doc/open-government-licence/ or write to the Information Policy Team, The National Archives, Kew, London TW9 4DU

email: psi@nationalarchives.gsi.gov.uk

\section{Next publication:}

Tuesday 6 September 2011

\section{Issued by:}

Office for National Statistics, Government Buildings, Cardiff Road, Newport NP10 8XG

\section{Media contact:}

Tel: $\quad$ Media Relations Office 08456041858

Emergency on-call 07867906553

Email: media.relations@ons.gsi.gov.uk

\section{Statistical contact:}

Tel: $\quad$ Richard Tonkin 01633456082

Email: $\quad$ richard.tonkins@ons.gsi.gov.uk

Website: www.ons.gov.uk 
Summary of cross-border mergers, acquisitions and disposals

Emillion

\begin{tabular}{|c|c|c|c|c|c|c|c|c|}
\hline & \multicolumn{4}{|c|}{ Transactions abroad by UK companies } & \multicolumn{4}{|c|}{ Transactions in the UK by foreign companies ${ }^{1}$} \\
\hline & \multicolumn{2}{|c|}{ Acquisitions } & \multicolumn{2}{|c|}{ Disposals } & \multicolumn{2}{|c|}{ Acquisitions } & \multicolumn{2}{|c|}{ Disposals } \\
\hline & Number & Value & Number & Value & Number & Value & Number & Value \\
\hline & CBAQ & CBBI & CBAS & CBBT & CBAU & $\mathrm{CBCQ}$ & CBAW & CBDB \\
\hline 2001 & 371 & 41473 & 139 & 28494 & 162 & 24382 & 62 & 4464 \\
\hline 2002 & 262 & 26626 & 128 & 7074 & 117 & 16798 & 60 & 7912 \\
\hline 2003 & 243 & 20756 & 136 & 8643 & 129 & 9309 & 55 & 3620 \\
\hline 2004 & 305 & 18709 & 118 & 5485 & 178 & 29928 & 54 & 5514 \\
\hline 2005 & 365 & 32732 & 110 & 12668 & 242 & 50280 & 61 & 8387 \\
\hline 2006 & 405 & 37412 & 89 & 21214 & 259 & 77750 & 55 & 14208 \\
\hline 2007 & 441 & 57814 & 104 & 10221 & 269 & 82121 & 66 & 7524 \\
\hline 2008 & 298 & 29670 & 71 & 12062 & 252 & 52552 & 49 & 5139 \\
\hline 2009 & 118 & 10148 & 37 & 5101 & 112 & 31984 & 38 & 7820 \\
\hline 2010 & $199^{\dagger}$ & $12414^{\dagger}$ & $73^{\dagger}$ & $11411^{\dagger}$ & $212^{\dagger}$ & $36643^{\dagger}$ & $58^{\dagger}$ & $9891^{\dagger}$ \\
\hline 2007 Q2 & 105 & 17617 & 39 & 1798 & 75 & 51511 & 26 & 5274 \\
\hline Q3 & 141 & 9873 & 23 & 3887 & 80 & 15044 & 12 & 903 \\
\hline Q4 & 87 & 25818 & 19 & 1068 & 53 & 9172 & 14 & 709 \\
\hline 2008 Q1 & 86 & 15946 & 15 & 787 & 86 & 21086 & 16 & 766 \\
\hline $\mathrm{Q} 2$ & 91 & 5729 & 19 & 5210 & 63 & 19964 & 17 & 2140 \\
\hline Q3 & 72 & 4247 & 19 & 4691 & 54 & 3228 & 11 & 568 \\
\hline Q4 & 49 & 3748 & 18 & 1374 & 49 & 8274 & 5 & 1665 \\
\hline 2009 Q1 & 17 & 3744 & 13 & 1299 & 28 & 12354 & 6 & 2157 \\
\hline Q2 & 32 & 2811 & 7 & 726 & 22 & 645 & 11 & 236 \\
\hline Q3 & 28 & 2574 & 7 & .. & 28 & 3934 & 8 & 2715 \\
\hline Q4 & 41 & 1019 & 10 &.. & 34 & 15051 & 13 & 2712 \\
\hline $2010 Q 1^{2}$ & $30^{\dagger}$ & $1027^{\dagger}$ & $13^{\dagger}$ & $2790^{\dagger}$ & 54 & 14371 & 8 & 332 \\
\hline Q2 & 49 & 2293 & 18 & 866 & $48^{\dagger}$ & $2841^{\dagger}$ & 15 & 1092 \\
\hline Q3 & 54 & 5308 & 18 & 4189 & 59 & 12405 & $19^{\dagger}$ & $3448^{\dagger}$ \\
\hline Q4 & 66 & 3786 & 24 & 3566 & 51 & 7026 & 16 & 5019 \\
\hline 2011 Q1 & 48 & 18299 & 14 & 1132 & 38 & 6394 & 12 & 707 \\
\hline
\end{tabular}

\section{Mergers and acquisitions abroad by UK companies: source of funding}

Emillion

\begin{tabular}{|c|c|c|c|c|c|c|c|c|}
\hline & \multicolumn{2}{|c|}{ Total $^{3}$} & \multirow{2}{*}{\multicolumn{2}{|c|}{$\begin{array}{c}\text { Direct transactions }{ }^{4} \\
\begin{array}{c}\text { Funds paid directly } \\
\text { by UK parent }\end{array}\end{array}$}} & \multicolumn{4}{|c|}{ Indirect transactions of which: } \\
\hline & \multirow[b]{2}{*}{ Number } & \multirow[b]{2}{*}{ Value } & & & \multicolumn{2}{|c|}{$\begin{array}{l}\text { Funded by loan } \\
\text { from UK parent }\end{array}$} & \multicolumn{2}{|c|}{$\begin{array}{l}\text { Funds raised } \\
\text { locally abroad }\end{array}$} \\
\hline & & & Number & Value & Number & Value & Number & Value \\
\hline & CBAQ & CBBI & CBBU & CBBV & CBBW & CBBX & CBBY & CBBZ \\
\hline 2001 & 371 & 41473 & 268 & 29545 & 90 & 8003 & 35 & 3925 \\
\hline 2002 & 262 & 26626 & 185 & 17000 & 52 & 5556 & 44 & 4070 \\
\hline 2003 & 243 & 20756 & 161 & 13043 & 54 & 5422 & 47 & 2291 \\
\hline 2004 & 305 & 18709 & 186 & 9250 & 69 & 8076 & 71 & 1383 \\
\hline 2005 & 365 & 32732 & 239 & 20234 & 69 & 5511 & 83 & 6987 \\
\hline 2006 & 405 & 37412 & 277 & 28800 & 96 & 5498 & 54 & 3114 \\
\hline 2007 & 441 & 57814 & 289 & 34880 & 105 & 14814 & 66 & 8120 \\
\hline 2008 & 298 & 29670 & 196 & 17972 & 75 & 6688 & 44 & 5010 \\
\hline 2009 & 118 & 10148 & 97 & 7456 & 17 & 2530 & 11 & 162 \\
\hline 2010 & $199^{\dagger}$ & $12414^{\dagger}$ & $149^{\dagger}$ & $10507^{\dagger}$ & $38^{\dagger}$ & $1166^{\dagger}$ & $26^{\dagger}$ & 741 \\
\hline
\end{tabular}

\footnotetext{
${ }^{\dagger}$ Indicates earliest revision, if any.

Disclosive data indicated by ..

3 Where a transaction is funded in more than one way, it is included in 'Number'

1 Includes acquisitions by foreign companies routed through their UK subsidiary companies

2 The deal identification threshold has been increased at Q1 2010 from

$£ 0.1 \mathrm{~m}$ to $£ 1.0 \mathrm{~m}$ and as a consequence there is a discontinuity in the numin each method but only once in 'Total'. Therefore numbers may not sum exactly across the columns.

4 Transactions for which details about financing have not been confirmed are included amongst direct transactions. The figures are subsequently revised ber of transactions reported.
} 


\begin{tabular}{|c|c|c|c|c|c|c|c|c|}
\hline & \multicolumn{2}{|c|}{ Total $^{1}$} & \multirow{2}{*}{\multicolumn{2}{|c|}{$\begin{array}{c}\text { Direct transactions }{ }^{2} \\
\begin{array}{c}\text { Funds paid directly } \\
\text { to UK parent }\end{array}\end{array}$}} & \multicolumn{4}{|c|}{ Indirect transactions of which: } \\
\hline & \multirow[b]{2}{*}{ Number } & \multirow[b]{2}{*}{ Value } & & & \multicolumn{2}{|c|}{$\begin{array}{l}\text { Repayment of loan made } \\
\text { by UK parent }\end{array}$} & \multicolumn{2}{|c|}{ Funds retained abroad } \\
\hline & & & Number & Value & Number & Value & Number & Value \\
\hline & CBAS & CBBT & CBCA & CBCB & $\mathrm{CBCC}$ & CBCD & CBCE & $\mathrm{CBCF}$ \\
\hline 2001 & 139 & 28494 & 102 & 22875 & 17 & 582 & 40 & 5037 \\
\hline 2002 & 128 & 7074 & 103 & 5709 &.. &.. &.. & \\
\hline 2003 & 136 & 8643 & 105 & 6920 & 12 & 1264 & 28 & 459 \\
\hline 2004 & 118 & 5485 & 87 & 3294 & 17 & 931 & 21 & 1260 \\
\hline 2005 & 110 & 12668 & 85 & 6530 & 13 & 923 & 22 & 5215 \\
\hline 2006 & 89 & 21214 & 65 & 17602 & 20 & 1860 & 21 & 1752 \\
\hline 2007 & 104 & 10221 & 87 & 7650 & 8 & 1393 & 20 & 1178 \\
\hline 2008 & 71 & 12062 & 54 & 7384 & 9 & 1021 & 15 & 3657 \\
\hline 2009 & 37 & 5101 & 33 & 4198 & 2 & .. & 3 & \\
\hline 2010 & $73^{\dagger}$ & $11411^{\dagger}$ & $59^{\dagger}$ & $8423^{\dagger}$ & 4 & 71 & $15^{\dagger}$ & $2917^{\dagger}$ \\
\hline
\end{tabular}

4 Mergers and acquisitions in the UK by foreign companies: source of funding

Emillion

\begin{tabular}{|c|c|c|c|c|c|c|c|c|}
\hline & \multicolumn{2}{|c|}{ Total $^{1}$} & \multirow{2}{*}{\multicolumn{2}{|c|}{$\begin{array}{c}\text { Direct transactions }^{2} \\
\begin{array}{c}\text { Funds paid directly to UK } \\
\text { by foreign company }\end{array}\end{array}$}} & \multicolumn{4}{|c|}{ Indirect transactions of which: } \\
\hline & \multirow[b]{2}{*}{ Number } & \multirow[b]{2}{*}{ Value } & & & \multicolumn{2}{|c|}{$\begin{array}{l}\text { Funded by loan } \\
\text { from foreign company }\end{array}$} & \multicolumn{2}{|c|}{ Funds raised in the UK } \\
\hline & & & Number & Value & Number & Value & Number & Value \\
\hline & CBAU & $\mathrm{CBCQ}$ & CBDC & CBDD & $\mathrm{CBHZ}$ & CBIA & CBIB & $\mathrm{CBIC}$ \\
\hline 2001 & 162 & 24382 & 113 & 11697 & 33 & 7797 & 36 & 4888 \\
\hline 2002 & 117 & 16798 & 93 & 13729 & 25 & 2179 & 9 & 890 \\
\hline 2003 & 129 & 9309 & 76 & 2978 & 37 & 3033 & 34 & 3298 \\
\hline 2004 & 178 & 29928 & 128 & 23527 & 39 & 2897 & 36 & 3504 \\
\hline 2005 & 242 & 50280 & 175 & 32193 & 61 & 11379 & 45 & 6708 \\
\hline 2006 & 259 & 77750 & 178 & 53578 & 63 & 6123 & 57 & 18049 \\
\hline 2007 & 269 & 82121 & 200 & 62475 & 52 & 6941 & 63 & 12705 \\
\hline 2008 & 252 & 52552 & 179 & 36101 & 50 & 8739 & 53 & 7712 \\
\hline 2009 & 112 & 31984 & 87 & 21091 & 20 & & 10 & \\
\hline 2010 & $212^{\dagger}$ & $36643^{\dagger}$ & $161^{\dagger}$ & $33540^{\dagger}$ & 36 & 1687 & $34^{\dagger}$ & $141 \ddot{6}^{\dagger}$ \\
\hline
\end{tabular}

\section{Disposals in the UK by foreign companies: funds realised}

Emillion

\begin{tabular}{|c|c|c|c|c|c|c|c|c|}
\hline & & & Direct tr & & & t transa & f which: & \\
\hline & & & $\begin{array}{l}\text { Funds } \\
\text { to fore }\end{array}$ & & $\begin{array}{r}\text { Repaym } \\
\text { forei }\end{array}$ & & $\begin{array}{r}\text { Fund } \\
\text { in }\end{array}$ & \\
\hline & Number & Value & Number & Value & Number & Value & Number & Value \\
\hline & CBAW & CBDB & CBID & CBIE & CBIF & CBIG & $\mathrm{CBIH}$ & CBII \\
\hline 2001 & 62 & 4464 & 40 & 1528 & 7 & 504 & 23 & 2432 \\
\hline 2002 & 60 & 7912 & 49 & 4217 & 3 & 85 & 14 & 3610 \\
\hline 2003 & 55 & 3620 & 39 & 994 & .. & & & \\
\hline 2004 & 54 & 5514 & 38 & 3564 & 9 & 369 & 17 & 1581 \\
\hline 2005 & 61 & 8387 & 47 & 4659 & 10 & 1488 & 17 & 2240 \\
\hline 2006 & 55 & 14208 & 39 & 6246 & 12 & 1923 & 15 & 6039 \\
\hline 2007 & 66 & 7524 & 49 & 4038 & 10 & 226 & 25 & 3260 \\
\hline 2008 & 49 & 5139 & 29 & 1485 & 9 & 682 & 15 & 2972 \\
\hline 2009 & 38 & 7820 & 32 & 6572 & - & - & 7 & 1248 \\
\hline 2010 & $58^{\dagger}$ & $9891^{\dagger}$ & $43^{\dagger}$ & $4961^{\dagger}$ & $5^{\dagger}$ & $928^{\dagger}$ & $15^{\dagger}$ & $4002^{\dagger}$ \\
\hline
\end{tabular}

$\dagger$ Indicates earliest revision, if any.

Disclosive data indicated by .

1 Where a transaction is funded in more than one way, it is included in 'Num-

ber' in each method but only once in 'Total'. Therefore numbers may not

sum exactly across the columns.
2 Transactions for which details about financing have not been confirmed are included amongst direct transactions. The figures are subsequently revised when details become available. 
614 Area analysis of acquisitions abroad by UK companies

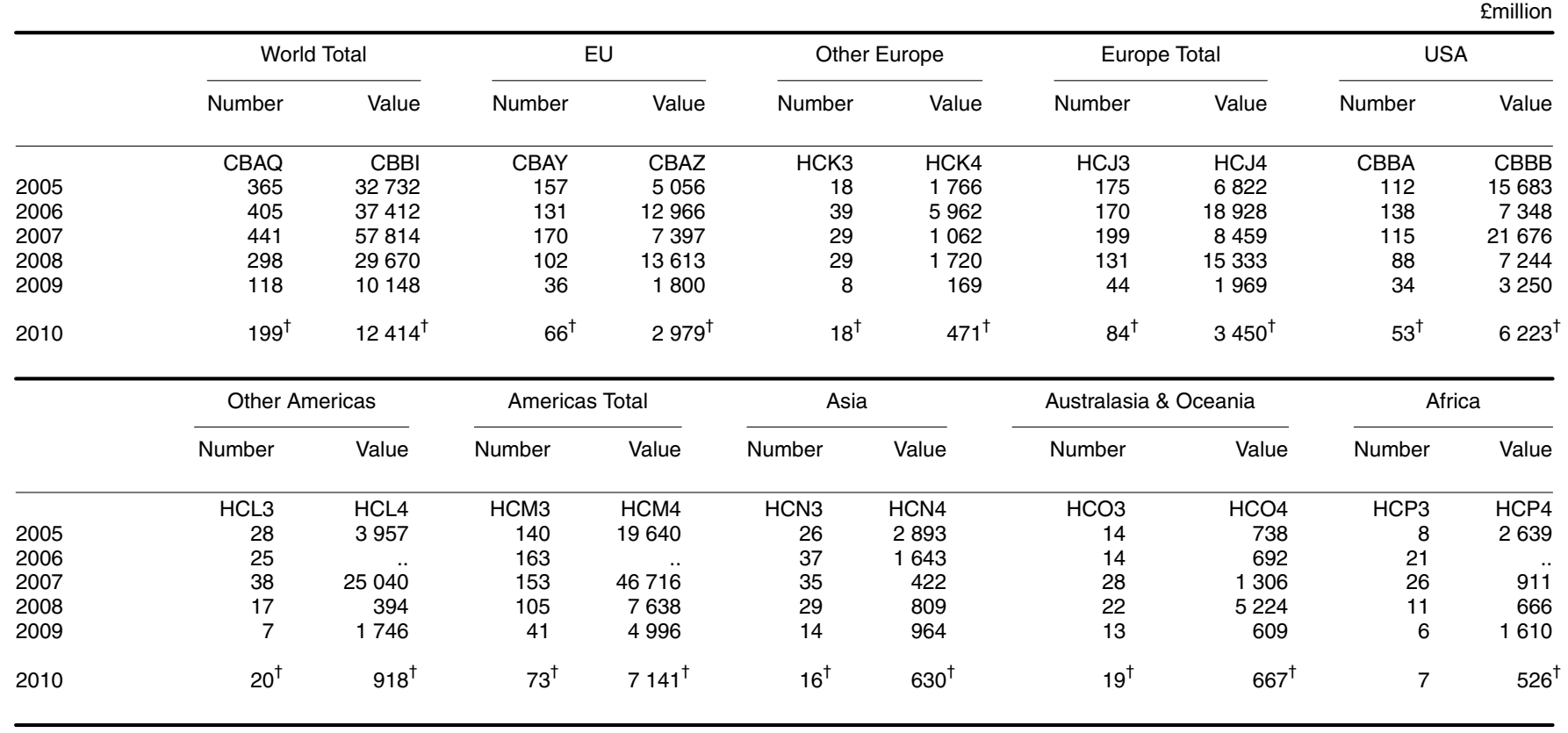

\section{$6 D$ Area analysis of disposals abroad by UK companies}

\begin{tabular}{|c|c|c|c|c|c|c|c|c|c|c|}
\hline & \multicolumn{2}{|c|}{ World Total } & \multicolumn{2}{|c|}{ EU } & \multicolumn{2}{|c|}{ Other Europe } & \multicolumn{2}{|c|}{ Europe Total } & \multicolumn{2}{|c|}{ USA } \\
\hline & Number & Value & Number & Value & Number & Value & Number & Value & Number & Value \\
\hline & CBAS & CBBT & CBBJ & CBBK & HCK5 & HCK6 & HCJ5 & HCJ6 & CBBL & CBBM \\
\hline 2005 & 110 & 12668 & 47 & 2059 & 11 & 109 & 58 & 2168 & 24 & 7033 \\
\hline 2006 & 89 & 21214 & 33 & 3198 & 7 & 2019 & 40 & 5217 & 25 & 7273 \\
\hline 2007 & 104 & 10221 & 44 & 3583 & 6 & 1032 & 50 & 4615 & 28 & 4654 \\
\hline 2008 & 71 & 12062 & 30 & 3598 & 2 & .. & 32 & .. & 22 & 6197 \\
\hline 2009 & 37 & 5101 & 15 & 2134 & 3 & 64 & 18 & 2198 & 7 & 1277 \\
\hline \multirow[t]{3}{*}{2010} & $73^{\dagger}$ & $11411^{\dagger}$ & $27^{\dagger}$ & $1529^{\dagger}$ & $5^{\dagger}$ & 263 & $32^{\dagger}$ & 1792 & $15^{\dagger}$ & $7465^{\dagger}$ \\
\hline & \multicolumn{2}{|c|}{ Other Americas } & \multicolumn{2}{|c|}{ Americas Total } & \multicolumn{2}{|l|}{ Asia } & \multicolumn{2}{|c|}{ Australasia \& Oceania } & \multicolumn{2}{|c|}{ Africa } \\
\hline & Number & Value & Number & Value & Number & Value & Number & Value & Number & Value \\
\hline & HCL5 & HCL6 & HCM5 & HCM6 & HCN5 & HCN6 & $\mathrm{HCO} 5$ & $\mathrm{HCO} 6$ & HCP5 & HCP6 \\
\hline 2005 & 2 & .. & 26 & .. & 12 & 760 & 5 & .. & 9 & 460 \\
\hline 2006 & 10 & .. & 35 & .. & 9 & 8085 & 4 & 14 & 1 & .. \\
\hline 2007 & 10 & 195 & 38 & 4849 & 8 & 195 & 3 & 533 & 5 & 29 \\
\hline 2008 & 6 & 1033 & 28 & 7230 & 7 & 388 & 2 & 234 & 2 & .. \\
\hline 2009 & 2 & 536 & 9 & 1813 & 3 & .. & 3 & 1002 & 4 & .. \\
\hline 2010 & $4^{\dagger}$ & $897^{\dagger}$ & $19^{\dagger}$ & $8362^{\dagger}$ & $11^{\dagger}$ & $117^{\dagger}$ & 5 & 609 & $6^{\dagger}$ & 531 \\
\hline
\end{tabular}

\footnotetext{
$\dagger$ Indicates earliest revision, if any.

Disclosive data indicated by ..
} 
$7 \Delta$ Area analysis of acquisitions in the UK by foreign companies

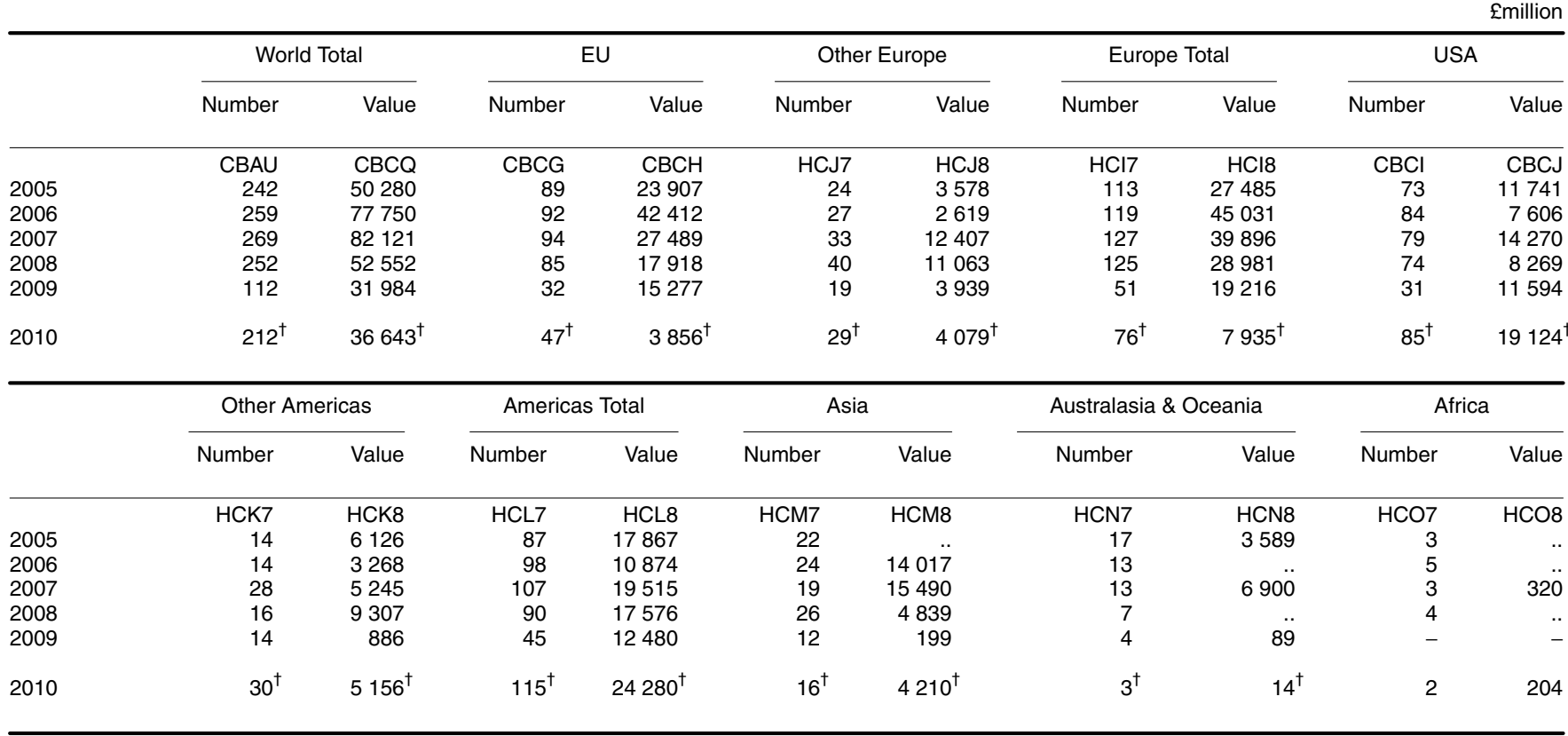

\section{Area analysis of disposals in the UK by foreign companies}

\begin{tabular}{|c|c|c|c|c|c|c|c|c|c|c|}
\hline & \multicolumn{2}{|c|}{ World Total } & \multicolumn{2}{|c|}{ EU } & \multicolumn{2}{|c|}{ Other Europe } & \multicolumn{2}{|c|}{ Europe Total } & \multicolumn{2}{|c|}{ USA } \\
\hline & Number & Value & Number & Value & Number & Value & Number & Value & Number & Value \\
\hline & CBAW & CBDB & CBCR & CBCS & HCJ9 & HCK2 & $\mathrm{HCl9}$ & HCJ2 & CBCT & CBCU \\
\hline 2005 & 61 & 8387 & 27 & 1873 & 8 & 516 & 35 & 2389 & 15 & 4736 \\
\hline 2006 & 55 & 14208 & 16 & 8670 & 5 & .. & 21 & .. & 22 & 1953 \\
\hline 2007 & 66 & 7524 & 12 & 2851 & 4 & .. & 16 & .. & 31 & 3063 \\
\hline 2008 & 49 & 5139 & 18 & 2628 & 9 & 447 & 27 & 3075 & 12 & 1359 \\
\hline 2009 & 38 & 7820 & 12 & 1370 & 6 & .. & 18 & .. & 10 & 4648 \\
\hline \multirow[t]{3}{*}{2010} & $58^{\dagger}$ & $9891^{\dagger}$ & $19^{\dagger}$ & $6722^{\dagger}$ & 10 & 271 & $29^{\dagger}$ & $6993^{\dagger}$ & $15^{\dagger}$ & 1216 \\
\hline & \multicolumn{2}{|c|}{ Other Americas } & \multicolumn{2}{|c|}{ Americas Total } & \multicolumn{2}{|l|}{ Asia } & \multicolumn{2}{|c|}{ Australasia \& Oceania } & \multicolumn{2}{|c|}{ Africa } \\
\hline & Number & Value & Number & Value & Number & Value & Number & Value & Number & Value \\
\hline & HCK9 & HCL2 & HCL9 & HCM2 & HCM9 & HCN2 & HCN9 & $\mathrm{HCO} 2$ & HCO9 & HCP2 \\
\hline 2005 & 3 & - & 18 & 4736 & 3 & .. & 4 & 1242 & 1 & .. \\
\hline 2006 & 3 & 1703 & 25 & 3656 & 6 & 204 & 2 & .. & 1 & 1 \\
\hline 2007 & 13 & 701 & 44 & 3764 & 5 & .. & 1 &.. & - & - \\
\hline 2008 & 4 & .. & 16 & .. & 3 & .. & 1 &.. & 2 & 93 \\
\hline 2009 & 4 & 42 & 14 & 4690 & 2 &.. & 1 &.. & 3 & - \\
\hline 2010 & $8^{\dagger}$ & $642^{\dagger}$ & $23^{\dagger}$ & $1858^{\dagger}$ & 3 & 1033 & 3 & 7 & - & - \\
\hline
\end{tabular}

\footnotetext{
${ }^{\dagger}$ Indicates earliest revision, if any

Disclosive data indicated by ..
} 
8 Summary of mergers and acquisitions in the UK by UK companies

Emillion

\begin{tabular}{|c|c|c|c|c|c|c|}
\hline & \multicolumn{2}{|c|}{$\begin{array}{l}\text { Total all mergers and } \\
\text { acquisitions }\end{array}$} & \multicolumn{2}{|c|}{$\begin{array}{l}\text { Mergers and acquisitions of } \\
\text { independent companies }\end{array}$} & \multicolumn{2}{|c|}{$\begin{array}{l}\text { Sales of subsidiaries } \\
\text { between company groups }\end{array}$} \\
\hline & Number & Value & Number & Value & Number & Value \\
\hline & AlHA & DUCM & DWVH & HIKB & DWVL & HIKC \\
\hline 2001 & 492 & 28994 & 319 & 21029 & 173 & 7965 \\
\hline 2002 & 430 & 25236 & 323 & 16998 & 107 & 8238 \\
\hline 2003 & 558 & 18679 & 392 & 10954 & 166 & 7725 \\
\hline 2004 & 741 & 31408 & 577 & 22882 & 164 & 8526 \\
\hline 2005 & 769 & 25134 & 604 & 16276 & 165 & 8858 \\
\hline 2006 & 779 & 28511 & 628 & 20180 & 151 & 8331 \\
\hline 2007 & 869 & 26778 & 698 & 19779 & 171 & 6999 \\
\hline 2008 & 558 & 36469 & 445 & 33469 & 113 & 3000 \\
\hline 2009 & 286 & 12195 & 198 & 11455 & 88 & 740 \\
\hline 2010 & $325^{\dagger}$ & $12605^{\dagger}$ & $243^{\dagger}$ & $7775^{\dagger}$ & $82^{\dagger}$ & $4830^{\dagger}$ \\
\hline 2007 Q2 & 212 & 10122 & 158 & 5543 & 54 & 4579 \\
\hline Q3 & 258 & 7846 & 209 & 6904 & 49 & 942 \\
\hline Q4 & 208 & 3161 & 172 & 2068 & 36 & 1093 \\
\hline 2008 Q1 & 172 & 4545 & 136 & 3506 & 36 & 1039 \\
\hline $\mathrm{Q} 2$ & 183 & 9593 & 158 & 9069 & 25 & 524 \\
\hline Q3 & 104 & 4133 & 77 & 3789 & 27 & 344 \\
\hline Q4 & 99 & 18198 & 74 & 17105 & 25 & 1093 \\
\hline 2009 Q1 & 88 & 8206 & 59 & 8072 & 29 & 134 \\
\hline Q2 & 59 & 729 & 41 & 579 & 18 & 150 \\
\hline Q3 & 62 & 1886 & 43 & 1652 & 19 & 234 \\
\hline Q4 & 77 & 1374 & 55 & 1152 & 22 & 222 \\
\hline $2010 \mathrm{Q} 1^{1}$ & 67 & 1361 & 50 & 825 & 17 & 536 \\
\hline Q2 & $95^{\dagger}$ & $2032^{\dagger}$ & $70^{\dagger}$ & $1272^{\dagger}$ & 25 & 760 \\
\hline Q3 & 80 & 2949 & 58 & 2017 & $22^{\dagger}$ & $932^{\dagger}$ \\
\hline Q4 & 83 & 6263 & 65 & 3661 & 18 & 2602 \\
\hline 2011 Q1 & 60 & 1163 & 43 & 749 & 17 & 414 \\
\hline
\end{tabular}

9 Mergers and acquisitions in the UK by UK companies: category of expenditure

Emillion

\begin{tabular}{|c|c|c|c|c|c|c|c|c|}
\hline & \multicolumn{5}{|c|}{ Expenditure } & \multicolumn{3}{|c|}{ Percentage of expenditure } \\
\hline & \multirow[b]{2}{*}{ Total } & \multicolumn{2}{|c|}{ Cash } & \multirow{2}{*}{$\begin{array}{l}\text { Issues of } \\
\text { ordinary }^{2} \\
\text { shares }^{2}\end{array}$} & \multirow{2}{*}{$\begin{array}{r}\text { Issues of fixed } \\
\text { interest } \\
\text { securities }^{2}\end{array}$} & \multirow[b]{2}{*}{ Cash } & \multirow[b]{2}{*}{$\begin{array}{l}\text { Issues of } \\
\text { ordinary shares }\end{array}$} & \multirow{2}{*}{$\begin{array}{r}\text { Issues of fixed } \\
\text { interest } \\
\text { securities }\end{array}$} \\
\hline & & $\begin{array}{r}\text { Independent } \\
\text { companies }\end{array}$ & Subsidiaries & & & & & \\
\hline $\begin{array}{l}2001 \\
2002 \\
2003 \\
2004 \\
2005\end{array}$ & $\begin{array}{l}\text { DUCM } \\
28994 \\
25236 \\
18679 \\
31408 \\
25134\end{array}$ & $\begin{array}{r}\text { DWVW } \\
8489 \\
9574 \\
8956 \\
12080 \\
13425\end{array}$ & $\begin{array}{r}\text { DWVX } \\
6704 \\
7991 \\
7183 \\
7822 \\
8510\end{array}$ & $\begin{array}{r}\text { AlHD } \\
12356 \\
6780 \\
1667 \\
10338 \\
2768\end{array}$ & $\begin{array}{r}\text { AlHE } \\
1445 \\
891 \\
873 \\
1168 \\
431\end{array}$ & $\begin{array}{r}\text { DWVY } \\
52 \\
69 \\
86 \\
63 \\
87\end{array}$ & $\begin{array}{r}\text { DWVZ } \\
43 \\
27 \\
9 \\
33 \\
11\end{array}$ & $\begin{array}{r}\text { DWWA } \\
5 \\
4 \\
5 \\
4 \\
2\end{array}$ \\
\hline $\begin{array}{l}2006 \\
2007 \\
2008 \\
2009 \\
2010\end{array}$ & $\begin{array}{l}28511 \\
26778 \\
36469 \\
12195 \\
12605^{\dagger}\end{array}$ & $\begin{array}{rl}13 & 671 \\
31 & 333 \\
2 & 937 \\
6 & 175^{\dagger}\end{array}$ & $\begin{array}{r}8131 \\
6507 \\
2851 \\
709 \\
4520^{\dagger}\end{array}$ & $\begin{array}{l}4909 \\
1910 \\
8435 \\
1560^{\dagger}\end{array}$ & $\begin{array}{r}335 \\
1691 \\
375 \\
114 \\
350^{\dagger}\end{array}$ & $\begin{array}{l}7 \ddot{6} \\
94 \\
30 \\
85^{\dagger}\end{array}$ & $\begin{array}{r}18 \\
5 \\
69 \\
12^{\dagger}\end{array}$ & $\begin{array}{l}2 \\
6 \\
1 \\
1 \\
3\end{array}$ \\
\hline $\begin{array}{r}2007 \text { Q2 } \\
\text { Q3 } \\
\text { Q4 }\end{array}$ & $\begin{array}{rl}10 & 122 \\
7 & 846 \\
3 & 161\end{array}$ & $\begin{array}{l}3605 \\
5545 \\
1697\end{array}$ & $\begin{array}{r}4361 \\
833 \\
1037\end{array}$ & $\begin{array}{r}1874 \\
358 \\
270\end{array}$ & $\begin{array}{r}282 \\
1110 \\
157\end{array}$ & $\begin{array}{l}78 \\
81 \\
86\end{array}$ & $\begin{array}{r}19 \\
5 \\
9\end{array}$ & $\begin{array}{r}3 \\
14 \\
5\end{array}$ \\
\hline $\begin{array}{r}2008 \text { Q1 } \\
\text { Q2 } \\
\text { Q3 } \\
\text { Q4 }\end{array}$ & $\begin{array}{r}4545 \\
9593 \\
4133 \\
18198\end{array}$ & $\begin{array}{r}2578 \\
8845 \\
3408 \\
16502\end{array}$ & $\begin{array}{r}913 \\
520 \\
328 \\
1090\end{array}$ & $\begin{array}{l}786 \\
187 \\
341 \\
596\end{array}$ & $\begin{array}{r}268 \\
41 \\
56 \\
10\end{array}$ & $\begin{array}{l}77 \\
98 \\
91 \\
97\end{array}$ & $\begin{array}{r}17 \\
2 \\
8 \\
3\end{array}$ & $\begin{array}{l}6 \\
- \\
1 \\
-\end{array}$ \\
\hline $\begin{array}{r}2009 \text { Q1 } \\
\text { Q2 } \\
\text { Q3 } \\
\text { Q4 }\end{array}$ & $\begin{array}{r}8206 \\
729 \\
1886 \\
1374\end{array}$ & $\begin{array}{r}332 \\
130 \\
1409 \\
1066\end{array}$ & $\begin{array}{l}128 \\
150 \\
214 \\
217\end{array}$ & $\begin{array}{r}7699 \\
437 \\
254 \\
45\end{array}$ & $\begin{array}{r}47 \\
12 \\
9 \\
46\end{array}$ & $\begin{array}{r}6 \\
38 \\
87 \\
94\end{array}$ & $\begin{array}{r}93 \\
60 \\
13 \\
3\end{array}$ & $\begin{array}{l}1 \\
2 \\
- \\
3\end{array}$ \\
\hline $\begin{array}{r}2010 \text { Q1 } \\
\text { Q2 } \\
\text { Q3 } \\
\text { Q4 }\end{array}$ & $\begin{array}{l}1361 \\
2032^{\dagger} \\
2949 \\
6263\end{array}$ & $\begin{array}{rl} & 765 \\
& 986^{\dagger} \\
1 & 165 \\
3259\end{array}$ & $\begin{array}{r}525 \\
714 \\
814^{\dagger} \\
2467\end{array}$ & $\begin{array}{l}58 \\
275^{\dagger} \\
839 \\
388\end{array}$ & $\begin{array}{l}13 \\
57^{\dagger} \\
131 \\
149\end{array}$ & $\begin{array}{l}95 \\
83^{\dagger} \\
68 \\
92\end{array}$ & $\begin{array}{r}4^{\dagger} \\
14^{\dagger} \\
28 \\
6\end{array}$ & $\begin{array}{l}1 \\
3 \\
4 \\
2\end{array}$ \\
\hline 2011 Q1 & 1163 & 497 & 412 & 235 & 19 & 78 & 20 & 2 \\
\hline $\begin{array}{l}+ \text { Indic } \\
\text { Disclos }\end{array}$ & $\begin{array}{l}\text { st revision } \\
\text { e indicated }\end{array}$ & & & $\begin{array}{r}1 \mathrm{~T} \\
\text { to } \\
\mathrm{ac} \\
2 \mathrm{Is}\end{array}$ & $\begin{array}{l}\text { mal identification th } \\
\text { m and as a cons } \\
\text { to the vendor col }\end{array}$ & $\begin{array}{l}\text { hold has } \\
\text { ence ther } \\
\text { ny as pay }\end{array}$ & $\begin{array}{l}n \text { increased from } \\
\text { a discontinuity in th } \\
\text { th. }\end{array}$ & $\begin{array}{l}10 \text { from } £ 0.1 \mathrm{~m} \\
\text { umber of trans- }\end{array}$ \\
\hline
\end{tabular}




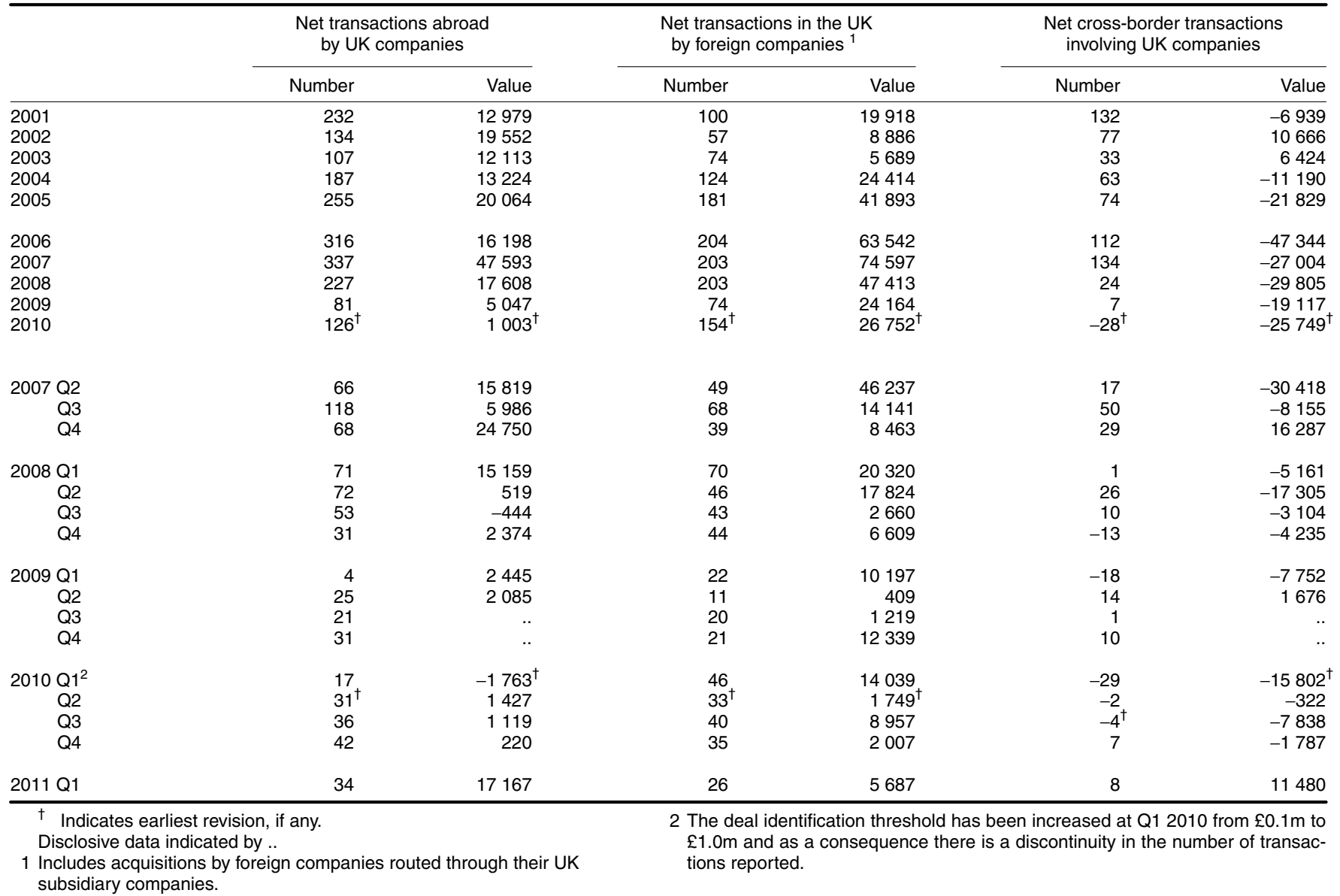

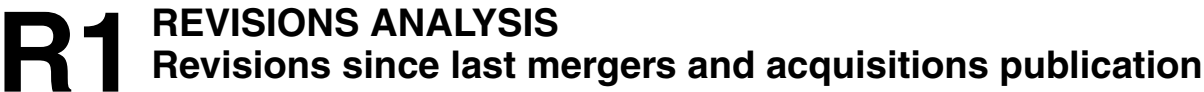

\begin{tabular}{|c|c|c|c|c|c|c|}
\hline & & 2010 & $\begin{array}{r}2010 \\
\text { Q1 }\end{array}$ & $\begin{array}{r}2010 \\
\text { Q2 }\end{array}$ & $\begin{array}{r}2010 \\
\text { Q3 }\end{array}$ & $\begin{array}{r}2010 \\
\text { Q4 }\end{array}$ \\
\hline \multicolumn{7}{|c|}{ Cross-border mergers, acquisitions and disposals } \\
\hline \multicolumn{7}{|c|}{ Transactions abroad by UK companies } \\
\hline Value of acquisitions & $\mathrm{CBBI}$ & 190 & 25 & -114 & 8 & 271 \\
\hline Value of disposals & CBBT & 1401 & 167 & - & 366 & 868 \\
\hline \multicolumn{7}{|c|}{ Transactions in the UK by foreign companies } \\
\hline Value of acquisitions & CBCQ & -2521 & - & -41 & 300 & -2780 \\
\hline Value of disposals & CBDB & 250 & - & - & 56 & 194 \\
\hline
\end{tabular}

Mergers and acquisitions in the UK by UK companies

Summary of transactions

Value of all acquisitions and mergers

Value of acquisitions of independent companies

Value of sales of subsidiary companies

Category of expenditure

Cash paid for independent companies

Cash paid for subsidiary companies

Issue of ordinary shares

Issue of fixed interest securities

$\begin{aligned} \text { DUCM } & 2483 \\ \text { HIKB } & 220\end{aligned}$

HIKB

HIKC

2263

$\begin{array}{rr}\text { DWVW } & 189 \\ \text { DWVX } & 2225 \\ \text { AlHD } & 18\end{array}$

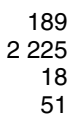

$\begin{array}{ll}- & 7 \\ - & - \\ - & 4 \\ - & 2\end{array}$

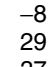

2478

178 2300

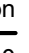

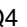


Next publication:

Tuesday 6 September 2011

Issued by:

Office for National Statistics, Government Buildings, Cardiff Road, Newport NP10 8XG

Media contact:

Tel: $\quad$ Media Relations Office 08456041858

Emergency on-call 07867906553

Email: $\quad$ media.relations@ons.gsi.gov.uk

Statistical contact:

Tel: $\quad$ Richard Tonkin 01633456082

Email: $\quad$ richard.tonkins@ons.gsi.gov.uk

Website: $\quad$ www.ons.gov.uk 